\title{
ANÁLISE DE INCÊNDIOS FLORESTAIS PARA GESTÃO PREVENTIVA E CONTROLE
}

Felipe Patrício das Neves - UFES (patriciofire193190@gmail.com), Nilton César Fiedler - UFES (niltoncesarfiedler@yahoo.com.br), Weslen Pintor Canzian SUZANO (weslenpcanzian@hotmail.com).

A análise dos atendimentos a incêndios florestais realizados por bombeiros militares é muito importante, em função do recente aumento no número de ocorrências, dos danos econômico sociais e a necessidade de preservação ambiental de remanescentes florestais. Em função da importância em se estabelecer ações preventivas e de controle economicamente viáveis e eficazes, o presente trabalho teve como objetivo analisar o perfil das ocorrências, verificar os períodos de maior incidência de incêndios florestais, regiões e bairros mais impactados. A área de estudo corresponde ao território do município de Linhares, no estado do Espirito Santo, localizado na região Sudeste do Brasil (1923'28" de latitude Sul e 4004'20" longitude Oeste de Greenwich, e área total de 3.504 $\mathrm{km}^{2}$ ). Foram utilizados registros de incêndios florestais do Centro Integrado Operacional de Defesa Social (CIODES), atendidos pelo Corpo de Bombeiros Militar do Estado do Espírito Santo (CBMES), entre 2015 e 2019. Além disso, para inclusão dos dados e identificação das áreas críticas de maior incidência, foram utilizados mapas do Sistema Integrado de Bases Geoespaciais do Estado do Espírito Santo (GEOBASES). Utilizando o software de geoprocessamento livre QGIS, versão 3.6, foram estabelecidos os 05 bairros que apresentaram maior incidência, servindo de sugestão de locais a serem priorizados para ações preventivas e estratégicas de combate. Além disso, foi possível notar as estações do ano de maior criticidade quanto a incêndios, e assim estabelecer as fases de planejamento e preparação, que devem anteceder a tais períodos. Como resultado da pesquisa, ao longo dos anos analisados, e após tratamento dos dados, registraram-se 1.029 atendimentos, destacando-se os bairros Canivete $(8,45 \%)$, Bebedouro $(6,8 \%)$, Planalto $(5,25 \%)$, Três Barras $(4,86 \%)$, além de Movelar e Rio Quartel (4,27\%). Os locais classificados em zona rural também receberam grande número de registros $(22,35 \%)$. Observou-se ainda que o bairro Centro, onde se encontra a unidade de bombeiros no município, não se destacou como de maior demanda (2,91\%), assim como outros bairros distribuídos pela região, porém faz parte da região central urbana de maior concentração de incêndios. Destacaram-se as estações do ano como períodos mais críticos o verão (dezembro a março), com $30,17 \%$, e a primavera (setembro a dezembro), com 25,33\%. Mapas de calor anuais, utilizando a ferramenta interpolador estimativa de densidade de Kernel, que destacam o grau de concentração de incêndios, indicaram surgimento de novas regiões de maior densidade distribuídas pelo interior do município. Para isso foi necessária a geocodificação (obtenção de coordenadas geográficas) dos endereços registrados nas ocorrências atendidas para cada ano do estudo. Durante o período analisado, foi possível observar que o maior número e distribuição de incêndios no município se deu nos anos de 2015 e 2019, destacando-se neste ano, além da central urbana (frequente em todos os anos), as regiões sul, sudoeste e nordeste. Pelos resultados, conclui-se que o perfil dos atendimentos fornece aos gestores informações relevantes capazes de potencializar a atividade de prevenção e controle de incêndios florestais. 
Palavras-chave: Proteção florestal; Prevenção de incêndios; Gestão Florestal.

Agradecimentos: os autores agradecem o apoio da UFES, por meio da oportunidade de realizar a pesquisa; e também ao Corpo de Bombeiros Militar do Estado do Espírito Santo, pelo apoio incondicional no fornecimento de dados e esclarecimentos realizados. 